\title{
WHEN THE GREAT MOTHER MET THE HARLEQUIN: JUNG AND NEUMANN ON ART, ARCHETYPES AND THE SPIRIT OF THE TIMES
}

MARTIN LIEBSCHER

PHANÊS • VOLUME $3 \cdot 2020 \bullet$ PP. 1-24

https://doi.org/10.32724/phanes.2020.Liebscher 


\begin{abstract}
Where Sigmund Freud famously failed to engage seriously and openly with Nietzsche's Thus spoke Zarathustra (1980 [1883-85]), C.G. Jung developed his psychological theory on the basis of a thorough critical engagement with the text and even dedicated a five-year long seminar series to its interpretation (1934-39). But similar to Freud before him he often developed a blind eye to his own contemporary literature and art. As Jung's writings on Joyce's Ulysses (Jung 1932) or Picasso's paintings make (Jung 1932a) evident he tended to reject the symbolic dimension of modernist art and literature and regarded it as a sheer product of the spirit of the times. Again, it was a psychologist of the next generation, Erich Neumann, whose adaptation of Jung's theory made it possible to apply archetypal theory to modernist art. This article will follow the key differences between Jung's and Neumann's understanding of art and literature by looking at their interpretations of main examples of modernism.
\end{abstract}

\title{
KEYWORDS
}

Erich Neumann, Pablo Picasso, James Joyce, the Great Mother archetype. 
batch of people in Zurich persuaded themselves that
Iwas gradually going mad and actually endeavoured
to induce me to enter a sanatorium where a certain
Doctor Jung (the Swiss Tweedledum who is not the be confused with the Viennese Tweedeldee, Dr. Freud) amuses himself at the expense (in every sense of the word) of ladies and gentlemen who are troubled with bees in their bonnets. (Joyce 1966:167).

This is the voice of James Joyce in a letter to Harriet Shaw Weaver from 24 June 1921, recounting his Zurich days of 1915, a time he spent writing extensively on his modernist masterpiece Ulysses (1984 [1922]). ${ }^{1}$ It was also the period of Tweedledum's personal crisis, who since 1913 had experienced a number of unsettling visions he was trying to come to terms with. The protocol of these visions in several black note books would eventually provide the material base for the Liber Novus or Red Book (Jung 2009). Joyce's Ulysses and Jung's Liber Novus do not only share the time and place, but as it seems - also their mode of creation with each other: one of the main novels of modernism and Jung's revision of the private protocols of his encounter with the collective unconscious are linked through the common experience of, what Jung called using a term coined by Pierre Janet an 'abaissement du niveau mental' - in both cases overcome by the ability of their authors to endure this decline of conscious ego control with the help of their creativity. ${ }^{2}$ However, whereas in the case of Joyce the aesthetic form of Ulysses would somehow emulate the mental

\footnotetext{
${ }^{1}$ Joyce referred in his letter in particular to Edith Rockefeller McGormick, who wanted Joyce to go into analysis with Jung. When he refused, she stopped supporting him financially (Loeb-Shloss 2003:277).

2 Jung on Ulysses: 'In Janet's psychology this phenomenon is known as abaissement du niveau mental. Among the insane it happens involuntarily, but with Joyce it is the result of deliberate training. All the richness and grotesque profundity of dream-thinking come to the surface when the fonction du réel, that is, adapted consciousness, is switched off. Hence the predominance of psychic and verbal automatism and the total neglect of any communicable meaning' (1932:112, n. 7).
} 
stage of fragmentation and dissolution of the ego, the Liber Novus forms a rather traditional narrative similar to nineteenth-century 'visionary' works such as Nietzsche's Zarathustra or Hölderlin's Hyperion.

In his study on schizophrenia and modernism, the American clinical psychologist Louis A. Sass attempted to show the affiliations between the psychotic condition of schizophrenia and the twentieth century avant-garde movement in literature and art (Sass 1994). Strangely enough, though he briefly mentions the case of Lucia Joyce, whom her father brought reluctantly to Jung for treatment in 1934-she was to some extent treated by Cary F. Baynes - Sass did not use Ulysses as an example to support his argument. Perhaps he refrained from doing so, because Jung had already taken on this task in his 'notorious' 1932 essay on Ulysses:

Even the layman would have no difficulty in tracing the analogies between Ulysses and the schizophrenic mentality. The resemblance is indeed so suspicious that an indignant reader might easily fling the book aside with the diagnosis 'schizophrenia'. (Jung 1932:§173).

Jung's essay is referred to as notorious as - at first glance-it seems to offer little more than the confession of his complete inability to deal with modernist literature: he utters about his difficulties of reading the text, counts the times he fell asleep, and uses the 'tapeworm' as a metaphor to explain the production mode of the novel. However, despite his barely disguised personal dislike of the novel, Jung does not qualify the text as the product of a schizophrenic mind:

It would never occur to me to class Ulysses as a product of schizophrenia. Moreover, nothing would be gained by this label, for we wish to know why Ulysses exerts such a powerful influence and not whether its author is a high-grade or a lowgrade schizophrenic. Ulysses is no more a pathological product than modern art is as a whole. (Jung 1932:§174).

But, and here Jung's attempt equals that of Sass, he detects an analogy between modernist art and schizophrenic symptoms. The artist desires and intentionally aims at what the schizophrenic lives through as a result of the destruction of his personality, and thereby gains, in contrast to the mentally ill, the unity of his artistic personality. But one might add 
here, it is not only the artist who aims at inducing this state:

The predominance of unconscious influences, together with the associated disintegration of the persona and the deposition of the conscious mind from power, constitute a state of psychic disequilibrium which, in analytical treatment, is artificially induced for the therapeutic purpose of resolving a difficulty that might block further development. (Jung 1928:\$252).

Jung, who hardly seems to be aware of the similarities between his analytical method and the artistic mode of production, calls modernist art a 'Mephistophelian perversion of sense into non-sense, of beauty into ugliness' (1932:§176) and describes Ulysses as a text that is insulting 'all our conventional feelings' and that 'brutally disappoints our expectations of sense and contents' (1932:§177). Jung explains his negative attitude towards the novel through his unmodern position that would, out of ill will, still suspect traces of synthesis and form: 'the resentment of the unmodern man who does not want to see what the gods have graciously veiled from his sight.' (1932:\$177) Ulysses, according to Jung, found its precursors in the pre-modern Dionysian exuberance of Nietzsche's Zarathustra and Ecce Homo, the second part of Goethe's Faust, or Hölderlin's Hyperion (1932:\$178), but these texts would still intend to recommend themselves to the public, a characteristic that would differentiate them from modernist novels such as Ulysses. One can deduce from this statement that the Liber Novus, insofar as it belongs to this pre-modernist group of 'visionary' texts, i.e. created by the overwhelming of the consciousness through unconscious contents, was also written with the intention to be understood and to convey a message, albeit to Jung himself. In Ulysses, Jung laments, one would search in vain for any symbolic contents. One can only imagine Jung's puzzlement when he came across Elijah's departure in a chariot over Donohoe's in Little Green Street ${ }^{3}$ or his second coming before the 'great and dreadful day' 4 in a brothel:

\footnotetext{
3 'When, lo, there came about them all a great brightness and they beheld the chariot wherein He stood ascend to heaven. And they beheld Him in the chariot, clothed upon in the glory of the brightness, having raiment as of the sun, fair as the moon and terrible that for awe they durst not look upon Him. And there came a voice out of heaven, calling: Elijah! Elijah! And He answered with a main cry: Abba! Adonai! And they beheld Him even Him, ben Bloom Elijah, amid clouds of angels ascend to the glory of the brightness at an angle of fortyfive degrees over Donohoe's in Little Green street like a shot off a shovel' (Joyce 1984 [1922]:741-2).
}

4 Malachi 4:5: 'Behold, I will send you Elijah the prophet before the coming of the 
FLORRY: (Sinking into torpor, crossing herself secretly.) The end of the world!

(A female tepid effluvium leaks out from her. Nebulous obscurity occupies space. Through the drifting fog without the gramophone blares over coughs and feetshuffling.)

THE GRAMOPHONE: Jerusalem!

Open your gates and sing

Hosanna...

(A rocket rushes up the sky and bursts. A white star falls from it, proclaiming the consummation of all things and second coming of Elijah. Along an infinite invisible tightrope taut from zenith to nadir the End of the World, a twoheaded octopus in gillie's kilts, busby and tartan filibegs, whirls through the murk, head over heels, in the form of the Three Legs of Man.)

THE END OF THE WORLD: (With a Scotch accent.) Wha'll dance the keel row, the keel row, the keel row?

(Over the possing drift and choking breathcoughs, Elijah's voice, harsh as a corncrake's, jars on high. Perspiring in a loose lawn surplice with funnel sleeves he is seen, vergerfaced, above a rostrum about which the banner of old glory is draped. He thumps the parapet.)

ELIJAH: No yapping, if you please, in this booth. Jake Crane, Creole Sue, Dove Campbell, Abe Kirschner, do your coughing with your mouths shut. Say, I am operating all this trunk line. Boys, do it now. God's time is 12.25 . Tell mother you'll be there.

great and dreadful day of the LORD' (KJV). 
Rush your order and you play a slick ace. Join on right here. Book through to eternity junction, the nonstop run. Just one word more. Are you a god or a doggone clod? If the second advent came to Coney Island are we ready? Florry Christ, Stephen Christ, Zoe Christ, Bloom Christ, Kitty Christ, Lynch Christ, it's up to you to sense that cosmic force. Have we cold feet about the cosmos? No. Be on the side of the angels. Be a prism. You have that something within, the higher self. You can rub shoulders with a Jesus, a Gautama, an Ingersoll. Are you all in this vibration? I say you are. You once nobble that, congregation, and a buck joyride to heaven becomes a back number. You got me? It's a lifebrightener, sure. The hottest stuff ever was. It's the whole pie with jam in. It's just the cutest snappiest line out. It is immense, supersumptuous. It restores. It vibrates. I know and I am some vibrator. Joking apart and, getting down to bedrock, A. J. Christ Dowie and the harmonial philosophy, have you got that? O. K. Seventyseven west sixtyninth street. Got me? That's it. You call me up by sunphone any old time. Bumboosers, save your stamps. (He shouts.) Now then our glory song. All join heartily in the singing. Encore! (He sings.) Jeru... (Joyce 1984 [1922]:1099-1100).

In contrast, Jung experienced Elijah as a wise man, who revealed the all-important secret about the symbolic content of the unconscious to him, something that, according to Jung, does not exist in Joyce's Ulysses:

I: 'Is it a hellish dream? Mary; our mother? What madness lurks in your words? The mother of our Savior, our mother? When I crossed your threshold today; I foresaw calamity. Alas! It has come. Are you out of your senses, Salome? Elijah, protector of the divine law, speak: is this a devilish spell cast by the rejected? How can she say such a thing? Or are both of you out of your senses? You are symbols and Mary is a symbol. I am simply too confused to see through you now.'

E: 'You may call us symbols for the same reason that you can also call your fellow men symbols, if you wish to. But we are just as real as your fellow men. You invalidate nothing and solve nothing by calling us symbols.'

I: 'You plunge me into a terrible confusion. Do you wish to be 
real?'

E: 'We are certainly what you call real. Here we are, and you

have to accept us. The choice is yours.' (Jung 2009:249).

It has been said-and it was indeed one of Jung's criticisms of Freud - that the Viennese Tweedeldee Freud had a tendency of pathologising literature, i.e. to interpret literary text as results of the neurotic condition of its author, or at least to deduce literary production from the psychological shortcomings of its author. In his reading of Joyce's work Jung is very careful not to fall into the same trap. He talks of analogies between madness and modernist literature - and Ulysses is declared a manifestation of the 'Zeitgeist', the 'spirit of the times'. But Jung himself seems incapable to link to this spirit. He has no cluewhat to do with the modernist text other than to ridicule it and to place it outside the framework of Analytical Psychology. He shares this inability to deal with the contemporary literature and art of his time with Freud a generation earlier. Where Freud failed to engage seriously and openly with texts like Nietzsche's Thus Spoke Zarathustra, Jung stepped in and openly incorporated Nietzschean thinking in his theory. The question arises: who stepped in, when Jung failed to engage with modernist literature and art? This is where Erich Neumann and his attempt to apply Jungian psychology to modernist art come into play.

Erich Neumann has often been described as one ofthe most important students of Jung, or perhaps the most important one. This verdict originates partially from Jung's preface to Neumann's first major work, Origins and History of Consciousness (1949). There, Jung emphasised the value of Neumann's study and honoured the book with an extraordinarily generous comment, stating that Neumann had continued labouring at the place where Jung had had to stop in his pioneering work-effectively declaring Neumann to be his successor (Jung 1949). Since Neumann's premature death in 1960 his reputation has declined, not least due to a lack of support by the Zurich school, and because of fierce attacks from the developmental school of Fordham (Liebscher 2015:lv-lix). But the question has been raised at times whether Neumann's work is an extension of Jung's thinking, an independent valid psychology, or a false and dangerous deviation from Analytical Psychology. The following considerations will try to elaborate on this question against the background of Neumann's understanding of modernist literature and art.

Erich Neumann was born in Berlin into an assimilated Jewish family. In contrast to his parents, he was a dedicated Zionist and was prepared to 
leave Germany for Palestine in 1933. He interrupted his journey to Tel Aviv for half a year to practice with Jung in Zurich (October to May, 1933-34). Besides this stay - and another one of two months in 1936-, there was no personal contact with Jung or the Zurich Jungians until 1947. Instead, there was an intense correspondence between Jung and Neumann. After the war, Neumann made annual trips to Switzerland from 1947 to 1960. In Ascona, he became one of the main contributors to the annual Eranos conference.

Although Neumann often complained about the distance to Jung and that he missed out on the latest developments, the separation also opened up the possibility of an independent development of his thinking. Depth Psychology and a New Ethic (1949a), written during the war in Tel Aviv, was received with great hostility in Zurich and its shortcomings were derogatively described - together with those of Origins and History of Consciousness published in the same year-as the result of Neumann's long absence from Zurich, which had prevented him from following and understanding the development of Analytical Psychology over the years. His later works such as Amor and Psyche (1952) or The Great Mother (1956) found more appreciation amongst the Jungian community. But until Neumann's death in 1960 his relationship with the Zurich followers of Jung remained rather tense.

But not least of all due to the physical distance, Neumann's understanding of contemporary art and literature was less shaped by Jung's view of the modernist art movement, which one can see from the very different art and literature he chose as subject for his depth-psychological research. This openness originated also from the fact that Neumann was a generation younger than Jung and had a different biographical background:

1. Neumann grew up in Berlin, which was a centre of modern art at the time. His formative years fell into the buzzling 1920s. His liberal upbringing would certainly allow him to notice the artistic developments around him. In comparison, Jung spent his childhood and adolescence in places like Kleinhüningen and Basle in the 1870s and 80s-brought up in the household of a pastor of the Swiss Reformed Church, a church that is inextricably linked with the iconoclastic teachings of the reformer Huldrych Zwingli.

2. From early on, Neumann had an interest in literature and wanted to become a writer himself. Poems and fragments of dramas date back to his school days such as a fragment of a dramatic play entitled Saul and the first act of a Judas drama, dated 20 November 1922, when Neumann was 
just about seventeen years old:

Judas: Johannes, erlöse mich! Ich stehe und warte

und ich harre dessen, der da kommen soll.

Das Dunkel ist eingewurzelt in die Nacht

und ich warte auf das Licht das mich blenden

wird, vor dem ich mich fürchte. Johannes,

hast Du wieder von dem Lichte geträumt?

[Judas: John, save me! I stand and wait

And long for the one to come.

The darkness is enrooted in the night

and I await the light that will blind me,

of which I am afraid.

John, did you dream once more of the light?].

(Sotheby's 2006:156).

This drama is followed by another unpublished manuscript on Jesus Christ, perhaps the continuation of the Judas play. Amongst his unpublished writings there is poetry from the years 1921 to 1929 , written in an expressionist style:

Wie kann der Mensch das Ungebärdige

Das Unbestimmte seines dunklen Blutes

Vergessen über dem ungestümen Drang der Abende 
Wo niemand singt mit den Stürmen,

Die fern vom Menschen zwischen den Sternen brausen.

Absage gilts und tiefere Trunkenheit

Denn unersättlich steht noch der heiße Tod

Das Aufgerissensein der verlassnen Erde.

Ob unter dem nie versiegenden Strom der Ewigkeit

Die in Berührung sich zärtlich verschwendet,

Noch neuere Köstlichkeit und menschenverändernde Nähe

Sich in uns ausströmt — einsam gespannt kreist doch

Der Genius uns, der einst uns abruft...

[How is it that one can forget the skittish

Indeterminacy of one's dark blood,

In the impetuous urge of evenings,

When no-one sings while the storms

Are roaring far beyond humanity among the stars.

There is denial and deeper drunkenness,

As fervid death stands there insatiable, 
The laceration of the forsaken soil.

If there, beneath the inexhaustible flow of eternity,

Tenderly lavishing itself,

New delight and life-changing intimacy

Pours out in us - lonely and drawn,

The Genius who will finally call us back encircles us]. (ibid:154).

He also wrote a novel entitled Der Anfang, which was partially published in 1932.

3. Before Neumann became interested in analytical psychology and embarked on the study of medicine, he enrolled at the University of Berlin for courses in philosophy, psychology, pedagogy, literature, history of arts, and Semitic studies (1923-26). He continued these studies in Erlangen and finished with a dissertation on the mystic language philosophy of the romantic writer Johann Arnold Kanne (Neumann 1928).

During this time Neumann befriended the young and talented student of philosophy Hannah Arendt. She had recently left Marburg, where she was involved in an affair with the philosophy lecturer Martin Heidegger, to continue her studies in Heidelberg with Karl Japers (Arendt $\&$ Heidegger 1999). The move was also due to married Heidegger's urging to avoid a public scandal. At the time she formed a friendship with Erich Neumann, Karl Frankenstein (1905-1990) and the expressionist writer Erwin Loewenson (1888-1963) (Young-Bruehl 1982: 66). Frankenstein, a friend of Neumann's from his school days at the Mommsen Gymnasium in Berlin, studied philosophy and psychology together with Neumann at the University of Erlangen. In 1935 he immigrated to British Mandate Palestine and became a Professor of Pedagogy and Special Education at the Hebrew University of Jerusalem. According to Arendt's biographer Elisabeth Young-Bruehl, all three men were attracted to the young Jewish student, but only Loewenson's advances were successful and they had a brief love affair in 1927. ${ }^{5}$ When Neumann died in 1960 Arendt wrote the ${ }^{5}$ A photography of Neumann and Arendt can be found in Löwenthal-Neumann (2006:158). 
following poem in her diaries:

30 Nov. 1960

Erich Neumann's death.

What remains of you? Nothing more than a hand, nothing more than the expectancy quivering in your fingers, when they grasped and closed in greeting.

For this grasp remained as a trace in my hand, which did not forget, which still sensed how you used to be when your mouth and your eyes long since failed you.

(Arendt 2002: 613). ${ }^{6}$

4. Neumann's interest in art and literature came alongside his fascination with Jewish mysticism, the Kabbalah, and Hasidism. He saw the revival of Hasidism (along the lines of Buber's understanding), next to the Hebrew language, as the major aspect of modern Jewish identity. His correspondence with Jung on this subject lead Neumann to write two volumes on The Roots of Jewish Consciousness (2019 [1934-40]). The result of Neumann's interest in the arts together with his Zionist conviction and the fascination with Hasidism were two studies on a couple of prominent Jewish contributors to modernism: Franz Kafka and Marc Chagall.

Neumann wrote a commentary on Kafka's novel Das Schloss and fifteen of his short stories, which he sent to Martin Buber, who praised his interpretations for their originality (Löwe 2014:377). ${ }^{7}$ What is remarkable about the Kafka commentary is that it was written as early as 1932. In comparison, Max Brod's seminal Kafka biography was only published in 1937. The emphasis of Neumann's interpretation is more on the Jewish character of Kafka's writing - he links certain themes to Kabbalistic and Hasidic traditions (e.g. in 'The Bucket Rider') — than on its psychological implications. This is not surprising, as the Kafka commentary was written years before Neumann met Jung for the first time.

In his 1956 Eranos lecture 'Creative Man and the Great Experience', Neumann returned to Kafka in order to explain the transpersonal quality of

\footnotetext{
${ }^{6}$ Translated by Heather McCartney.

7 Neumann's commentary on The Trial was published in Neumann (1958), its English translation and the cathedral chapter in Neumann 1979:3-112. For a detailed list of Neumann's unpublished typescripts on Kafka see Sotheby's catalogue (2006:146-147).
} 
human creativity:

\begin{abstract}
However different the experiences of artists may be, and in whatever different ways these experiences may appear to them and through them, their creativity always represents a breakthrough in which the dimension of the purely personal opens out into the realm of the intrinsic essence of things which constitutes the suprapersonal background of reality. [Neumann 1956a: 160].

[So verschieden auch die Erfahrungen der Künstler sind und auf wie verschiedene Weise sie sich in ihnen und durch sie auch darstellen, immer ist ihr Schöpferisches der Durchbruch durch das Nur-Personale der Erfahrung in ein Wesenhaftes, das den überpersönlichen Hintergrund der Wirklichkeit ausmacht].
\end{abstract}

Neumann does not deny Kafka's father complex, so tragically expressed in the 'Letter to the Father', but behind the complex he sees the transpersonal (or archetypal) field of the sacrifice of the son, e.g. in 'The Judgment'. The sacrifice of Isaac and the death of Christ on the cross are cited as two examples that connect to the protest of the modern human against God that Jung articulates in 'Answer to Job'. And, here we find a link to Neumann's early Kafka interpretation of 'The Judgment', according to which Kafka's literature is the expression of collective Jewish suffering faced with a surrounding hostile world that is created and directed by an almighty and cruel father. The creative human being is, according to Neumann, able to endure (and even to free herself or himself from) her or his personal suffering through the creation or making visible of something that belongs to reality. And this is where the personal realm transcends into the transpersonal.

The difference to Jung's reading of Ulysses is evident. Jung rejects the symbolic dimension of the text and regards it as a sign of the times. Joyce deliberately attempts, according to Jung, to avoid any collective archetypal meaning. A bad pun it is, where Jung expresses his astonishment that Ulysses has nothing in common with the ancient Greek myth. Neumann, in contrast, sees the transpersonal as the fundamental quality of any creative production. Arguably, Kafka makes it easier for Neumann than Joyce for Jung, but there is one creative personality, though not a writer but an artist, which both psychologists wrote about: Pablo Picasso. 
In the aforementioned essay, Neumann follows up the example of Kafka with that of Picasso. He refers to Picasso's drawings originating from late 1953 to early 1954. Those drawings followed a personal crisis when the aging artist was left by his long-time partner Françoise Gilot and his mistress Genevieve Laporte around the same time. ${ }^{8}$ The topic of these 180 drawings is almost exclusively the artist and his model. The woman, depicted as a goddess, beautiful and unapproachable at the same time, is contrasted by the figure of the artist, who is 'in contrast to the superior being of the naked and silent woman human and all too human' [Neumann 1956: 99; my translation] ['im Gegensatz zum überlegenen Dasein der nackten und schweigenden Frau menschlich und allzumenschlich'] The variety of the depiction of this relationship transcends the individual case of Picasso's desperation:

Abreaction of a dream, the complex as a wound, the personal an ignition and inducement-but in Picasso's passionate concentration all of that is re-melted, without a single drawing being drafted as a symbol. Here the opposition between artist and model changes into that between man and woman, consciousness and reality, art and life, creative spirit and inconceivable nature. In the artistic creation all that and more becomes a visible one, a higher unity of psyche and world, life and archetype, singularity and eternity appears in a very mundane symbol: the artist and his model as symbol of a 'great experience' of the unity of reality. [Neumann 1956:100].

['Abreaktion eines Traumes, der Komplex als Wunde, das Personale als Zünding und Anlass - aber in der leidenschaftlichen Konzentration Picassos wird all dies umgeschmolzen, und ohne dass ein einziges Blatt als Symbol gestaltet ist, wird der Gegensatz von Maler und Modell zu dem von Mann und Frau, von Bewusstsein und Wirklichkeit, von Kunst und Leben, von formendem Geist und unfassbarer Natur. In der künstlerischen Gestaltung aber verbindet sich all dies und mehr zu einem Sichtbaren, und die höhere Einheit von Psyche und Welt, Leben und Archetyp, Einmaligkeit und Ewigkeit erscheint in dem höchst irdischen Symbol: der Maler und sein Modell als Symbol einer "Großen Erfahrung" vom Ganzen der Wirklichkeit'].

${ }^{8}$ A Suite of 180 Drawings by Picasso Verve 29-30, ed. Leiris, Michel; West, Rebecca (Harcourt, Brace, and Co. 1954). 
Jung wrote on Picasso shortly after the publication of his essay on Joyce in 1932. The Kunsthaus Zürich had just presented the first major exhibition of Picasso's work, from 11 September to 30 October 1932, when Jung was asked to comment on Picasso's art for the Neue Zürcher Zeitung. He calls Joyce Picasso's literary brother and stresses the link between modernist art and illness once more, when he assures the reader that Picasso's psychological problems - insofar as expressed in his artare analogous to those of his patients [Jung 1932a:§205].

Jung understood creative art as an attempt to deal with the unconscious and to connect this inner side with an outer conscious and material expression, something he frequently asked his patients to do. Jung divided the paintings of his patients into two groups: the neurotic, which he saw as expressions of feelings and form a complete whole, and the schizophrenic, which Jung describes as lacking any feeling, full of contradictions, and formally fragmented: 'The image leaves one cold or seems terrifying due to its paradoxical, emotionally disturbing, spooky or grotesque ruthlessness towards the viewer. Picasso belongs to this group.' [Jung 1932a:208] ['Das Bild läßt kalt oder wirkt erschreckend wegen seiner paradoxen, gefühlsstörenden, schauerlichen oder grotesken Rücksichtslosigkeit auf den Betrachtenden. Picasso gehört zu dieser Gruppe.'] [\$208] This passage caused a stir, when published in the NZZ, and Jung felt obliged to add a footnote to the published version in Wirklichkeit der Seele (1934):

I do not regard Picasso as psychotic, nor Joyce, but count them to a vast group of human beings, whose disposition it is not to react to a profound disturbance of their soul with a common psycho-neurosis but with a schizoid complex of symptoms. [Jung 1934:153 n. 3; my translation] ['Ich bezeichne Picasso ebensowenig wie Joyce als psychotisch, sondern rechne sie bloß zu jener umfangreichen Menschengruppe, deren Habitus es ist, nicht mit einer gewöhnlichen Psychoneurose auf eine tiefgehende seelische Störung zu reagieren, sondern mit einem schizoiden Symptomenkomplex'].

Schizophrenics, Jung continues, do not try to convey a symbolical content, which becomes obvious in Joyce or Picasso. Picasso's personal artistic development equals a process of a night-sea journey (blue phase), reaching down into the abaissment du niveau mental or katabasis eis 
antron. There he encounters the Harlequin, a figure that Jung compares to Nietzsche's ropedancer from Zarathustra, doubting Picasso's ability to escape the hell in which he has descended. As becomes evident in the case of Picasso, Jung does not use archetypal theory to understand the art-work, but to understand the artist and his psychological development, whereas Neumann goes indeed beyond the personal to find the transpersonal significance that art, and indeed modernist art, conveys. What this means for an analytical psychological interpretation of art becomes clear in the case of Neumann's understanding of Chagall's paintings.

Neumann's text, entitled 'Note on Marc Chagall' (1954) originated from a presentation in Tel Aviv and was first published in the journal Merkur. For Neumann, great art offers a glimpse beyond the personal realm of the artist. It is a contemporary representation of timeless, collective unconscious contents. Hence, to search for an individual intention in Chagall's work would mean reducing his art to a personal level. And this is where Chagall's creation of art differed from the surrealists:

But - and this is the very crux of the matter-Chagall is no Surrealist working with the blind unconscious of Freudian free association. A profound, but by no means unformed, reality makes itself felt in his work. The dream law of his paintings flows from a unity of feeling, reflected not only in the intrinsic colour development but also in the relationship between the symbols that order themselves round the symbolic centre of the picture. These symbolic centres of Chagall's pictures are unquestionably spontaneous products of his unconscious, and not constructions of his ego. (Neumann 1954:135-136).

In his interpretation of Chagall's work, we can find two of Neumann's main psychological interests. First, the question of Jewish psychology: in Chagall's art the traditional Jewish belief in prophecies makes place for a new kind of prophetic message. In these paintings Neumann can see the return to childhood, where the personal and the supra-personal, the inner and the outer become one:

For what is childhood but the time of great events; the time in which the great figures are close at hand and look out from behind the corner of the house next door; the time in which the deepest symbols of the soul are everyday realities, and the world is still radiant with its innermost depth? This childhood reaches 
back to the earliest prehistory and embraces Abraham's angels as tenderly as the neighbor's ass; [...] In this childhood there is yet no separation between personal and supra-personal, near and far, inward soul and outward world; the life stream flows undivided, joining godhead and man, animal and world, in the glow and colour of the nearby. (Neumann 1954:138).

Due to this quality the art work transcends the realm of the personal and can reveal the development and change of the Jewish soul as a collective message. This message is connected to the second pillar of Neumann's psychological model: the aspect of the feminine. In Chagall's art the patriarchal characteristics of the prophetic Jewry are replaced by matriarchal qualities. Neumann sees in this the return of the Shekinah from exile. The Shekinah as the female principle of God, also known as Malkuth, unites with Tifereth, the male principle of God. But this new Jewish emphasis on the feminine, claims Neumann, is no compensatory development to the old prophetic Jewry, but a development of a new prophecy that goes beyond the Jewish tradition. It is the union between the anima and the Self that forms the deeper message of Chagall's art.

In Chagall's paintings, such as 'Madonna of the Village,' Neumann saw an archetypal representation of the archetype of the Great Mother. From 1947 to 1951, Neumann was working on his monograph on that archetype - originally intended as an introduction to the publication of the 1938 Eranos exhibition catalogue. As became evident from the Chagall interpretation, the matriarchal aspect formed a substantial aspect of Neumann's understanding of art, an aspect that was even more accentuated in his extensive interpretation of Henry Moore's work, published posthumously in 1961 under the title The archetypal world of Henry Moore (Neumann 1961).

In Moore's art, Neumann could find both archetypal representations he was interested in: the reclining figure of the feminine and the mother and child relationship - for Neumann, both, of course, representations of the Great Mother archetype. Moore himself confirmed his obsession with these motifs:

The 'Mother and child' idea is one of my two or three obsessions, one of my inexhaustible subjects ... But the subject itself is eternal and unending, with so many sculptural possibilities in it - a small form in relation to a big form protecting the 
small one, and so on. It is such a rich subject, both humanly and compositionally, that I will always go on using it. (Moore 1979:29).

In his interpretation, Neumann describes the art of Moore as the development of the feminine in relation to the child. It starts with the protective aspect of the mother, the image of the cavity: ontogenetically, this represents the mother's protection the child experiences in the first month; on a phylogenetic level this positive aspect of the archetype of the Great Mother has found its expressions in images and worship of fertility goddesses.

Overtime, says Neumann, onecandetectanincreasingdehumanisation of Moore's art and an increasing fascination with the 'opening out' - as Moore called it. This mysterium of the 'opening out' cannot, according to Neumann, be reduced solely to a Freudian understanding. For Neumann these sculptures give the opportunity to experience what he calls the 'Einheitswirklichkeit' [unity of reality]. Through the use of the tactile sense one can experience these openings as the primal experience of childhood. The individual mother experience merges here with the archetypal. It is the mystery of the night sea journey - the way into the inner side of nature, where the motherly body changes into the earth mother.

During the war, Moore's objects, claimed Neumann, turned away from the positive aspect of the archetype; nevertheless, even in his drawings of the air-raid bunkers during the war the motif remains still the same: it is the depiction of the inside of the earth, the protective cover, the shelter. Only, in this case, the figures are depicted in an in-between state of sleep and death and start to reveal the other, darker side of the archetype of the Great Mother. Already in the reclining figures from 1939 one can clearly see the negative side of the archetype: here the Great Mother is not depicted anymore as a goddess of fertility, but of death:

Whereas the covering positive quality [of the archetype] is
linked to the symbol of the robe or vesture and the blanket, the
expression of its deadly destructive opposite is the bleakness and
nakedness, the reduction to the mechanical and ghostly aspect of
the skeleton, which is stripped of all its organic wealth.
['Während der bergend-positive Charakter mit dem Symbol des
Gewandes und der Decke verbunden ist, ist der Ausdruck seines
tödlich-zerstörenden Gegensatzes die Kahlheit und Nacktheit, PHANÊS 
die Reduktion auf das Mechanisch-Geisterhafte des aller organischen Fülle entkleideten Skelettes'.]. (Neumann 1961: 81)

But in a Jungian twist, this polarisation leads in the development of Moore's art to a unifying third. The union of opposites shows itself in Moore's post-war sculpture of the triads (the Norns or Moirai) and the emergence of the father in his family group sculptures.

In his article on the reception of Moore's work, the art historian Julian Stallabrass highlights the importance of Jungian art criticism for the time-leading away from the all-too-obvious biographical interpretations:

[Both Digby and] Neumann saw Moore's work as a flight from civilisation and its products, from intellect, material progress and individualism. Civilisation over-privileges the patriarchal values of technology and mechanism, and Moore's obsession with the mother-archetype is a natural reaction against this. [...]

For Neumann, Moore's anti-naturalistic distortions have nothing to do with modernism, but are solely a means through which this archetype can be more forcefully expressed. (Stallabrass 1992).

I disagree with this verdict as it seems only to reiterate the criticism brought forward against Jung, albeit in a reversed way. Neumann, in contrast to Jung, does not speak out against Moore's art as modernist. Yes, on the one hand, he understands creative art as a representation of the spirit of the times, which can be seen in the values of the time. But, on the other hand, he states that behind these one can also discover an unconscious collective layer - and this archetypal content forms the interest of Neumann. For Neumann, the modernist and archetypal interpretations do not exclude each other; and the fact that Neumann can apply archetypal criticism to modernist art is precisely where he differs from Jung's approach.

Neumann's psychological interpretation of Moore's art is also one of the rare cases where the artist concerned engaged with the interpretation and reacted to it. It seems opportune to finish this article with a verdict by the artist about his interpreter:

Part of the excitement of sculpture is the associations it can arouse, quite independent of the original aims and ideas of the sculptor. But I do not have any desire to rationalise the eroticism 
in my work, to think out consciously what Freudian or Jungian symbols may lie behind what I create. That I leave for others to do. I started to read Erich Neumann's book on my work, The Archetypal World of Henry Moore [1959], in which he suggests a Jungian interpretation, but I stopped halfway through the first chapter, because I did not want to know about these things, whether they were true or not. I did not want such aspects of my work to become henceforth self-conscious. I feel they should remain subconscious and the work should remain intuitive. Perhaps the associations it can arouse are all the stronger for that very reason. (Moore 2002:115).

University College London

m.liebscher@ucl.ac.uk

\section{REFERENCES}

Arendt, Hannah. 2002. Denktagebuch. Edited by Ursula Ludz and Ingeborg Nordmann. 2 volumes. Munich: Piper.

Arendt, Hannah \& Martin Heidegger. 1999. Briefe 1925 bis 1975 und andere Zeugnisse. Edited by Ursula Ludz. 2nd edition. Frankfurt: Vittorio Klostermann.

Joyce, James. 1984 [1922]. Ulysses: A Critical and Synoptic Edition Prepared by Hans Walter Gabler with Wolfhard Steppe and Claus Melchior. New York \& London: Garland Publishing.

Joyce, James. 1966. Letters of James Joyce. Volume 1. New York: Viking. Jung, Carl Gustav. 1928. The relation between the ego and the unconscious. Collected Works of C. G. Jung. vol. 7, §§202-406. 1932. “Ulysses”: A Monologue.' Collected Works of C. G. Jung. vol. $15, \S \S 163-203$. 1932a. 'Picasso.' Collected Works of C.G. Jung. vol. 15, §§204 214.

1934. Wirklichkeit der Seele. Anwendungen und Fortschritte der neueren Psychologie. Zürich: Rascher.

1949. 'Foreword to Neumann The Origins and History of Consciousness.' Collected Works of C. G. Jung. vol. 18, §§1234-1237. 
2009. The Red Book: Liber Novus. Edited and with an Introduction by Sonu Shamdasani. Trans. by Mark Kyburz, John Peck, and Sonu Shamdasani. London: W.W. Norton \& Company.

Loeb Shloss, Carol. 2003. Lucia Joyce: To Dance in the Wake. London: Bloomsbury.

Liebscher, Martin. 2015. 'Introduction.' In Erich Neumann and Carl Gustav Jung. Analytical Psychology in Exile. The Correspondence of C.G. Jung and Erich Neumann. Edited by Martin Liebscher. Translated by Eather McCartney. Princeton, NJ: Princeton University Press: xi-lix.

Löwe, Angelica. 2014. Aufder Seite der inneren Stimme: Erich NeumannLeben und Werk. München: Verlag Karl Alber.

Löwenthal-Neumann, Rali. 2006. 'My father, Dr Erich Neumann.' Harvest. International Journal for Jungian Studies 52 (2):148-160.

Moore, Henry. 1979. Henry Moore Drawings 1969-79. New York: Wildenstein.

2002. Writings and Conversations. Edited by Alan Wilkinson. Berkeley: University of California Press.

Neumann, Erich. 1928. Johann Arnold Kanne. Ein vergessener Romantiker. Ein Beitrag zur Geschichte der mystischen Sprachphilosophie. Berlin: Verlag Reuter \& Reichard.

1932. Chapter of the unpublished novel Der Anfang. In Julius Wassermann (ed.). Zwischen den Zelten: junge jüdische Autoren. Berlin: Die Nachricht:135-155.

2019 [1934-40]. The Roots of Jewish Consciousness. Edited by Ann Conrad Lammers. 2 volumes. London: Routledge.

1949. Ursprungsgeschichte des Bewusstseins. Zürich: Rascher; English translation as The Origins and History of Consciousness. Translated by R.F.C. Hull. Princeton, NJ: Princeton University Press, 1954.

1949a. Tiefenpsychologie und Neue Ethik. Zurich: Rascher. English translation by Eugene Rolfe: Depth Psychology and a New Ethic. London: Hodder \& Stoughton, 1969; reprint: Massachusetts: Shambhala, 1990.

1952. 'Eros und Psyche. Ein Beitrag zur seelischen Entwicklung 
des Weiblichen.' In Apuleius Amor und Psyche. Zürich: Rascher:75-217. English translation as 'The psychic development of the feminine: a commentary on the tale by Apuleius'. Translated by Ralph Manheim in Apuleius Amor and Psyche. New York: Pantheon Books, 1956:57 161.

1954. 'Bemerkung zu Mark Chagall.' In Kunst und schöpferisches Unbewusstes. Umkreisung der Mitte. Volume 3. Zürich: Rascher. English as 'Note on Marc Chagall.' In Art and the Creative Unconscious: Four Essays. Princeton, NJ: Princeton University Press, 1959:135-148.

1956. Die große Mutter. Der Archetyp des großen Weiblichen. Zurich: Rhein-Verlag. Again as Die große Mutter. Die weiblichen Gestaltungen des Unbewussten. Düsseldorf: Patmos, 2003. English translation as The Great Mother. An Analysis of the Archetype by Ralph Manheim. London: Routledge and Kegan Paul, 1955.

-1956a. 'Der schöpferische Mensch und die „Große Erfahrung“.' In Der schöpferische Mensch. Zürich: Rhein Verlag, 1959. English translation as 'Creative Man and the "Great Experience".' In The Essays of Erich Neumann. Volume 3. Princeton, NJ: Princeton University Press:131-202.

1958. "Aus dem ersten Teil des Kafka-Kommentars: "Das Gericht".' In Geist und Werk. Aus der Werkstatt unserer Autoren. Zum 75. Geburtstag von Dr. Daniel Brody.Zürich: Rhein Verlag:175-196. English translation by Eugene Rolfe as 'Kafka's "The Trial": An Interpretation through Depth Psychology.' In Creative Man, Bollingen series LXI/2 . Princeton, NJ: Princeton University Press, 1979:3-75.

1961. Die archetypische Welt Henry Moores. Zürich: Rascher; English translation by R.F.C. Hull as The Archetypal World of Henry Moore. Princeton, NJ: Princeton University Press, 1985.

1979. Creative Man. Five Essays. Translation by Eugene Rolfe. Bollingen Series LXI/2. Princeton, NJ: Princeton University Press.

Nietzsche, Friedrich. 1980 [1883-85]. Also sprach Zarathustra. Kritische Studienausgabe. 15 volumes. Edited by Mazzino Montinari and Giorgio Colli. Volume 4. Berlin, New York: de Gruyter. English translation by Adrian Del Caro as Thus spoke Zarathustra. Edited by Adrian Del Caro and Robert Pippin. Cambridge: Cambridge University Press, 2006.

Sass, Louis A. 1994. Madness and Modernism: Insanity in the Light of Modern Art, Literature, and Thought. Harvard: Harvard University 
Press.

Sotheby's. 2006. Music and continental manuscripts. London: Sotheby's, 30 November.

Stallabrass, Julian. 1992. 'The Mother and Child Theme in the Work of Henry Moore'. In Henry Moore. Mutter und Kind/Mother and Child. Leeds: Henry Moore Foundation:13-39.

Young-Bruehl, Elisabeth (1982): Hannah Arendt. For the love of the world. New Have: Yale University Press. 